\title{
Microbiological quality of air in free-range and box-stall stable horse keeping systems
}

\author{
Katarzyna Wolny-Koladka (iD
}

Received: 9 November 2017 / Accepted: 26 March 2018 / Published online: 7 April 2018

(C) The Author(s) 2018

\begin{abstract}
The aim of this study was to assess the microbiological quality of air in three horse riding centers differing in the horse keeping systems. The air samples were collected in one facility with free-range horse keeping system and two with box stalls of different sizes. The samples were collected over a period of 3 years (2015-2017), four times per year (spring, summer, autumn, winter) to assess the effect of seasonal changes. The prevalence of aerobic mesophilic bacteria, mold fungi, actinomycetes, Staphylococcus spp., and Escherichia coli was determined by the air collision method on Petri dishes with appropriate microbiological media. At the same time, air temperature, relative humidity, and particulate matter concentration $\left(\mathrm{PM}_{10}\right.$, $\mathrm{PM}_{2.5}$ ) were measured. It was found that the horse keeping system affects the occurrence of the examined airborne microorganisms. Over the 3-year period of study, higher temperature and humidity, as well as particulate matter concentration-which notoriously exceeded limit values - were observed in the facilities with the box-stall system. The air sampled from the largest horse riding center, with the largest number of horses and the box-stall system of horse keeping, was also characterized by the heaviest microbiological contamination. Among others, bacteria from the following genera: Staphylococcus spp., Streptococcus spp., Bacillus spp., and E. coli and fungi from the genera
\end{abstract}

K. Wolny-Koładka $(\bowtie)$

Department of Microbiology, University of Agriculture in Cracow, Mickiewicza Ave 24/28, 30-059 Cracow, Poland e-mail: katarzyna.wolny@urk.edu.pl
Aspergillus, Fusarium, Mucor, Rhizopus, Penicillium, Trichothecium, Cladosporium, and Alternaria were identified in the analyzed samples.

Keywords Horses · Air sampling · Bacteria · Fungi . Box-stall stable $\cdot$ Free-range

\section{Introduction}

Stables and other livestock buildings are not only a place for breeding and keeping animals, but also a work environment for people. Sanitary condition of air in stables has a direct effect on the health and well-being of people working with horses and the animals themselves. The causes of pollutant accumulation include frequent in such places high organic dust concentration, as well as small airflow inside rooms where animals are kept. In livestock buildings, air pollution originates mainly from animals, their feces, feed, and litter (Lloyd et al. 2003). Bioaerosol-forming microorganisms of livestock rooms are characterized by opportunistic virulence, but in cases of reduced immunity, periodically occurring in humans or animals, the air may be the source of pathogenic strains that cause zoonoses and epizootic diseases. Airborne microorganisms that may pose an epidemiological threat and can be found in livestock premises include enteropathogenic strains of Escherichia coli and other bacteria of fecal origin as well as Staphylococcus spp., Pseudomonas spp., Acinetobacter spp., and Erwinia spp., that can dwell in the litter or settle on the dust particles and together pose 
a health threat in the form of bioaerosol (Zucker et al. 2000; Elfman et al. 2009; Witkowska et al. 2012; Korzekwa et al. 2015). Mold fungi, including Cladosporium spp., Alternaria spp., Aspergillus spp., Penicillium spp., Fusarium spp.; their spores and metabolites; mycotoxins, and allergenic actinomycetes also pose a major threat; their presence in the air of stables negatively affects the health of humans and animals (Korzekwa et al. 2015). Toxicological hazards occur especially in those livestock rooms where negligence leads to the accumulation of feces, contaminated feed, dirt, and excessive humidity. Often, causes of poor sanitary condition include technological defects (e.g., inadequate material and construction solutions, lack of ventilation), improper operation, or negligence of repairs of facilities for animals (Duchaine et al. 2000; Chang et al. 2001). It should be emphasized that horses, their lovers, and caregivers spend a lot of time in stables and may be exposed to the harmful bioaerosol, which in consequence can result in lung diseases (Elfman et al. 2009). Particulate matter (PM) affects the abundance of bioaerosol-forming microorganisms as it is the main transport agent for biological particles (Frąk et al. 2014). Standards containing limit concentrations of $\mathrm{PM}_{10}$ and $\mathrm{PM}_{2.5}$ in Poland are included in the Regulation of the Minister of Environment of 24 August 2012 on the levels of certain substances in the air (Regulation 2012). The surface of particulate matter fragments contains microorganisms, which altogether penetrate into the respiratory system. Biological particles of diameters smaller than $7 \mu \mathrm{m}$ (respirable fraction) are a significant problem; those with a diameter of 4.7$7 \mu \mathrm{m}$ deposit mainly in the nasopharynx; particles of a diameter 3.3-4.7 $\mu \mathrm{m}$ reach the trachea and primary bronchi; 1.1-3.3 $\mu \mathrm{m}$ particles reach the secondary and terminal bronchi, while those smaller than $1.1 \mu \mathrm{m}$ may pass into alveoli (Górny and Dutkiewicz 2002). Bioaerosol particles smaller than $5 \mu \mathrm{m}$ may stay suspended in the air, while the larger ones undergo sedimentation (Chmiel et al. 2015).

In horses, as in humans, respiratory diseases are a huge problem. After orthopedic disorders, they are the second most important cause of exercise dysfunction in these animals. In young individuals, the most common are lung and upper respiratory tract diseases caused by infectious agents such as bacteria, fungi, actinomycetes, viruses, and toxins of microbial origin. In horses older than 7 years of age, the most common causes of this type of diseases are allergic conditions. RAO (recurrent airways obstruction) previously called COPD (chronic obstructive pulmonary disease), which is a disorder similar to human asthma, is the lung disease most commonly encountered in both recreational and sports horses. In the course of this disease, the horse wears quickly, coughs, and has a white discharge from nostrils (Witkowska et al. 2012).

At present, we have four main horse keeping systems: box stalls, tethering, run pen, and free-range (Waran 2002). The horse keeping system depends on the race, age, sex, and destination of the horses as well as the possibilities of the facility. In this study, concentration of bioaerosol was determined in the horse riding centers that differ in the horse keeping system, i.e., box-stall and free-range types; hence, these two types are described below. The most popular type of horse keeping is the box-stall system that restricts both movement and contact with other animals. It is often used, particularly in the case of noble breeds, or especially valuable individuals such as foals, stallions, sports horses, and aggressive or sick animals. It is also a very convenient and cost-effective way of keeping horses that do not require frequent supervision, while at the same time provides easy access to the animals. However, it is extremely important that the box stalls meet certain parameters with respect to microclimate, construction technology, and parameters affecting animal welfare. It should be remembered that this is not the optimal system for horses, as those animals have a strong herd instinct. On the other hand, the free-range system which provides horses with the possibility of unrestricted movement and contact with other animals is the most suited to the nature of horses. Mutual contacts within the flock enable to establish the hierarchy and to keep animals in peace. It is important to select the appropriate individuals, eliminating aggressive and malicious ones. Although access to horses on the pasture may be difficult and at the same time their observation is necessary, economically, it is an extremely cost-effective type of horse keeping. The free-range system is ideal for Hutsul horses that are resistant to adverse climatic condition and have a strong herd instinct (Waran 2002). However, regardless of the horse keeping system, the conditions in which they stay must be optimal enough and adapted to the needs of animals in order to maintain them in good health and condition.

Animal welfare and hygiene of employees of the horse riding centers, as well as adequate cleanliness at the stables, are a way to prevent the spread of pathogenic 
microorganisms. Therefore, finding increased concentrations of particulate matter and the number of selected microbial groups in the tested air should encourage taking measures in order to eradicate harmful microorganisms. Currently, there are no uniform regulations determining acceptable concentrations of microorganisms in the air of livestock premises (Gołofit-Szymczak and Górny 2010). In addition, research on this subject usually concerns pig, cattle, or chicken farms where animals are kept in high density (Witkowska et al. 2012). In stables, microbiological contamination may reach different levels depending on many factors such as construction systems, type of ventilation, size of premises, density of stocking, microclimatic conditions, and type of litter. For that reason, studies on the concentration of airborne microorganisms in stables should be conducted in order to determine the potential health risks for both humans and horses, often extremely valuable for their caregivers (Witkowska et al. 2012).

The aim of the conducted study was to assess the microbiological quality of air in stables with different sizes of box stalls and in the stable with the free-range horse keeping system. On this basis, it was expected to determine how the horse maintenance system affects the concentration and composition of bioaerosol.

\section{Material and methods}

\section{Sampling points}

The microbiological quality of air was investigated in three, differing in the type of horse keeping systems, horse riding centers located in the Lesser Poland voivodeship (Poland). Horse Riding Center Pegaz in Kraków (OJK Pegaz) is an example of a small stable, with seven closed and eight boxes opening to the outside. There are 13 horses in the facility, including Shetland pony, half-blood noble horse, and Wielkopolski horse, and the remaining two are horses owned by private people. The horses kept in the center are recreational horses, and apart from private horses, there is no rotation. The sampling sites were located in five points. Points no. 1 and 2 were located inside the closed stable, points no. 3 and 4 -in the open box stalls - and the point no. 5 in front of the stable, outdoors (control point). The Horse Riding Club Szary in Michałowice (KJK Szary) is one of the largest and most modern stables in Poland; it has a total of c.a. 100 closed boxes. KJK Szary keeps recreational and sports horses of many breeds, including Shetland pony, half-blood noble horse, Wielkopolski horse, and Belgian hot-blooded horse, and the facility also runs a guesthouse for horses, hence the large rotation of animals. Sampling sites were located in 10 points. Points no. 1 to 9 were located inside the stable, whereas point no. 10 (control) was situated outdoors, in front of the stable. The sampling sites in OJK Pegaz and KJK Szary were evenly distributed so that the air in the stable could be analyzed in a representative way. In both stables (OJK Pegaz and KJK Szary), a gravity ventilation system was used. The Hutsul Pony Stud Farm in Nielepice (SKH Nielepice) is the only one that runs the non-stable animal husbandry. The horses stay in the open air all year round. The Hutsul horses are kept on pastures in two separate herds (10 mares, 18 rolls, and 2 stallions) and only use shelters in wooden sheds without doors. Sampling sites were located in four points relevant for the operation of the stud (1-roof for riders; 2 - saddle room; 3 -roof for horses; 4 - paddock). The number of horses in all three riding centers remained the same during the study period.

Air sampling, microbiological analysis

Air samples were collected every 4 months (springApril; summer-July; autumn-October; winterJanuary), for 3 years, resulting in 12 sampling campaigns. Air for microbiological testing was sampled in triplicates using the MAS-100 (Merck, Switzerland) air sampler. Each time from the height of $1.5 \mathrm{~m}, 100 \mathrm{l}$ of air was collected over $1 \mathrm{~min}$, in accordance with the requirements specified in the Polish Standard (PN-Z-04008-08 1989). The number of microorganisms was determined by culturing on the following microbiological media: mesophilic bacteria (Trypticasein Soy Lab Agar, BTL, Poland), mold fungi (Malt Extract Agar, BTL, Poland), actinomycetes (Actinomycete Isolation Lab Agar, BIOCORP, Poland), and staphylococci (Chapman agar, BTL, Poland). In addition, the presence of Escherichia coli in the air of the tested points was determined using the chromogenic medium TBX (Tryptone Bile X-glucuronide, BTL, Poland). After sampling, the cultures were incubated at the following conditions: mesophilic bacteria and staphylococci $37^{\circ} \mathrm{C}$, $48 \mathrm{~h}$; mold fungi $28^{\circ} \mathrm{C}, 3-5$ days; actinomycetes $28^{\circ} \mathrm{C}, 5-7$ days; and E. coli $44^{\circ} \mathrm{C}, 48 \mathrm{~h}$. At each sampling point, air temperature and relative humidity 
(Kestrel 4000, Nielsen-Kellerman, USA) as well as the concentration of particulate matter $\left(\mathrm{PM}_{10}, \mathrm{PM}_{2.5}\right.$, sampling time $-1 \mathrm{~min}$; sampling interval $-1 \mathrm{~min}$.) (dust meter DustTrak, TSI) were measured. After incubation, the characteristic colonies of tested microorganisms were counted and the results were given as the number of colony forming units per cubic meter of air $\left(\mathrm{CFU} \cdot \mathrm{m}^{-3}\right)$, with the consideration of the positive hole correction table as recommended by the air sampler manufacturer (Operator's Manual MAS-100TM professional Microbial Air Monitoring System for the Microbiological Testing of Air n.d.). Preliminary identification of airborne microorganisms was also performed using diagnostic keys (Domsch et al. 1980; Holt 1994). During the entire study period, it was checked whether the horses participating in the experiment remained in good condition and were not subjected to pharmacological treatment.

\section{Statistical analysis}

The statistical analysis was conducted in Statistica v. 12.5 software (StatSoft, US). A two-way ANOVA test was performed to determine the statistical significance of temporal and spatial variation in the bioaerosol. Pearson's correlation coefficient $r$ was calculated between the abundance of airborne microorganisms and microclimatic parameters (temperature, relative humidity, $\mathrm{PM}_{10}$, and $\mathrm{PM}_{2.5}$ ).

\section{Results and discussion}

Considering the fact that microclimatic conditions that prevail in livestock premises favor the presence of many groups of microorganisms, their large number and diversity should not be surprising (Korzekwa i in. 2015). On the other hand, the presence of pathogenic bacteria and fungi and their metabolites can pose a serious threat to the health of people and animals (Wolny-Koładka and Malina 2017). Based on a 3-year study on microbial contamination of air in the non-stable and box-stall system of horse keeping, the presence of bacteria from the following genera was found in the analyzed material: Staphylococcus, Streptococcus, Bacillus, Micrococcus, Diplococcus, and Sarcina. The following genera were identified in the case of fungi: Aspergillus, Fusarium, Mucor, Rhizopus, Penicillium, Trichothecium, Cladosporium, and Alternaria. As shown by other authors, these are microorganisms typical for the environment of livestock premises (Dutkiewicz et al. 1994; Zucker et al. 2000; Witkowska et al. 2012). On the basis of the environmental interview, it was not found that the horses, included in the experiment, were sick or treated pharmacologically in the study period. Due to the lack of applicable standards in Poland that would determine the limit concentrations of airborne microorganisms in livestock premises, the results obtained in this study were referred to the criteria proposed by the National Institute of Hygiene (PN-89/Z-04111/02 1989; PN-89/ Z04111/03 1989) presented in Table 1, and - in the case of Staphylococcus spp. and E. coli-to the papers by other authors (Dutkiewicz et al. 1994; Zucker et al. 2000; Korzekwa et al. 2015; Budzińska et al. 2016).

The assessment of dust concentration was based on the limits set by the Regulation of the Minister of the Environment of 24 August 2012 on the levels of certain substances in the air, which contain the limit values for the particulate matters $\mathrm{PM}_{10}$ and $\mathrm{PM}_{2.5}$ (Regulation 2012).

The results of studies concerning mean concentrations of individual groups of bioaerosol-forming microorganisms are presented in Tables 2, 3, and 4.

The limit values for the concentration of bacteria were not exceeded at OJK Pegaz in the control point (5) outside the stables and in points 3 (autumn) and 4 (autumn, winter), which were located in the boxes opening to the outside. In the remaining points, the air was qualified as moderately or heavily polluted with these microorganisms. In OJK Pegaz, bacteria were most abundant in summer $\left(2756 \mathrm{CFU} \cdot \mathrm{m}^{-3}\right)$ and their smallest numbers were observed in winter $\left(864 \mathrm{CFU} \cdot \mathrm{m}^{-3}\right)$. The concentration of airborne fungi did not exceed the permissible level at any of the sampling points. Their mean concentrations were on the other hand the highest in summer $\left(1202 \mathrm{CFU} \cdot \mathrm{m}^{-3}\right)$ and autumn $\left(1000 \mathrm{CFU} \cdot \mathrm{m}^{-3}\right)$ but decreased significantly in winter $\left(233 \mathrm{CFU} \cdot \mathrm{m}^{-3}\right)$. Large variation in the number of actinomycetes was observed between the sampling points. Therefore, based on their periodic presence in the analyzed sites, the air was classified as clean or moderately or heavily polluted with these microorganisms. Spring was the season of the year with the highest mean number of airborne actinomycetes $\left(271 \mathrm{CFU} \cdot \mathrm{m}^{-3}\right)$, whereas winter $\left(13 \mathrm{CFU} \cdot \mathrm{m}^{-3}\right)$ and autumn $\left(17 \mathrm{CFU} \cdot \mathrm{m}^{-3}\right)$ were the least favorable for their prevalence. During the entire study period, the air collected in the points located within the stables was 
Table 1 Limit values $\left(\mathrm{CFU} \cdot \mathrm{m}^{-3}\right)$ concerning microbial air contamination

\begin{tabular}{llll}
\hline Mesophilic bacteria & Mold fungi & Actinomycetes & Level of air contamination \\
\hline$<1000$ & $3000-5000$ & $<10$ & No contamination \\
$1000-3000$ & $5000-10,000$ & $10-100$ & Moderate contamination* \\
$>3000$ & $>10,000$ & $>100$ & Heavy contamination** \\
\hline
\end{tabular}

Own study based on Polish Standard (PN-89/Z-04111/02 1989; PN-89/Z04111/03 1989)

Single (*) and double asterisk (**) interpretation of data is in Tables 2,3 , and 4

most heavily polluted with staphylococci. Only in points 3 and 4 (winter, boxes opening to the outside), there was a decrease in the concentration of Staphylococcus spp. Moreover, in winter, the average number of staphylococci $\left(370 \mathrm{CFU} \cdot \mathrm{m}^{-3}\right)$ was the smallest as compared to the rest of the year. Small numbers of E. coli were detected in all sampling points at OJK Pegaz in spring and summer (Table 2).

Table 2 Mean number $\left(\mathrm{CFU} \cdot \mathrm{m}^{-3}\right)$ of airborne microorganisms - OJK Pegaz

\begin{tabular}{|c|c|c|c|c|c|c|}
\hline \multirow[t]{2}{*}{ Season } & \multicolumn{6}{|c|}{ Sampling point } \\
\hline & 1 & 2 & 3 & 4 & 5 & Mean \\
\hline \multicolumn{7}{|c|}{ Mesophilic bacteria } \\
\hline Spring & $2559 * \mathrm{c}$ & $2412 * \mathrm{c}$ & $1357 * a b$ & $2868 * \mathrm{c}$ & $354 \mathrm{ab}$ & 1910 \\
\hline Summer & $3923 * * \mathrm{c}$ & $4367 * * \mathrm{c}$ & $1914 * a b$ & $3041 * * \mathrm{c}$ & $535 \mathrm{ab}$ & 2756 \\
\hline Autumn & $1980 * a b c$ & $2450 * \mathrm{c}$ & $847 \mathrm{ab}$ & $2167 * b c$ & $78 \mathrm{a}$ & 1504 \\
\hline Winter & $1916^{*} a b$ & $2205 * \mathrm{bc}$ & $75 \mathrm{a}$ & $94 \mathrm{a}$ & $28 \mathrm{a}$ & 864 \\
\hline \multicolumn{7}{|l|}{ Mold fungi } \\
\hline Spring & $1150 \mathrm{ab}$ & $1031 \mathrm{ab}$ & $1494 \mathrm{ab}$ & $460 \mathrm{ab}$ & $247 \mathrm{ab}$ & 876 \\
\hline Summer & $1414 \mathrm{ab}$ & $1544 \mathrm{~b}$ & $827 \mathrm{ab}$ & $1528 \mathrm{ab}$ & $696 \mathrm{ab}$ & 1202 \\
\hline Autumn & $1890 \mathrm{~b} a b$ & $2420 \mathrm{~b}$ & $512 \mathrm{ab}$ & $107 \mathrm{ab}$ & $70 \mathrm{ab}$ & 1000 \\
\hline Winter & $586 \mathrm{ab}$ & $358 \mathrm{ab}$ & $74 \mathrm{ab}$ & $62 \mathrm{a}$ & $87 \mathrm{ab}$ & 233 \\
\hline \multicolumn{7}{|c|}{ Actinomycetes } \\
\hline Spring & $552 * * \mathrm{a}$ & $701 * * \mathrm{a}$ & $28 * \mathrm{a}$ & $57 * \mathrm{a}$ & $16^{*} \mathrm{a}$ & 271 \\
\hline Summer & $86^{*} \mathrm{a}$ & $35^{*} \mathrm{a}$ & $6 \mathrm{a}$ & $75^{*} \mathrm{a}$ & $4 \mathrm{a}$ & 41 \\
\hline Autumn & $0 \mathrm{a}$ & $46^{*} \mathrm{a}$ & $0 \mathrm{a}$ & $41 * \mathrm{a}$ & $0 \mathrm{a}$ & 17 \\
\hline Winter & $29 * \mathrm{a}$ & $16^{*} \mathrm{a}$ & $15^{*} \mathrm{a}$ & $2 \mathrm{a}$ & $0 \mathrm{a}$ & 13 \\
\hline \multicolumn{7}{|c|}{ Staphylococcus spp. } \\
\hline Spring & $2152 \mathrm{ab}$ & $1163 \mathrm{ab}$ & $1534 \mathrm{ab}$ & $2479 a b$ & $76 \mathrm{a}$ & 1481 \\
\hline Summer & $1534 \mathrm{ab}$ & $3752 \mathrm{~b}$ & $1706 \mathrm{ab}$ & $1992 \mathrm{ab}$ & $202 \mathrm{a}$ & 1837 \\
\hline Autumn & $2037 \mathrm{ab}$ & $2617 \mathrm{ab}$ & $225 \mathrm{a}$ & $2204 \mathrm{ab}$ & $0 \mathrm{a}$ & 1417 \\
\hline Winter & $820 \mathrm{ab}$ & $890 \mathrm{ab}$ & $69 \mathrm{a}$ & $56 \mathrm{a}$ & $16 \mathrm{a}$ & 370 \\
\hline \multicolumn{7}{|l|}{ E. coli } \\
\hline Spring & $25 \mathrm{ab}$ & $15 a b$ & $13 a b$ & $31 \mathrm{ab}$ & $18 \mathrm{ab}$ & 20 \\
\hline Summer & $31 \mathrm{ab}$ & $47 \mathrm{~b}$ & $13 a b$ & $8 a b$ & $1 \mathrm{a}$ & 20 \\
\hline Autumn & $0 \mathrm{a}$ & $0 \mathrm{a}$ & $0 \mathrm{a}$ & $0 \mathrm{a}$ & $0 \mathrm{a}$ & 0 \\
\hline Winter & $0 \mathrm{a}$ & $0 \mathrm{a}$ & $0 \mathrm{a}$ & $0 \mathrm{a}$ & $0 \mathrm{a}$ & 0 \\
\hline
\end{tabular}

The different letters within a column indicate a significant difference at $p<0.05$ according to Tukey's test

* Moderate air contamination described in Table 1

**Heavy air contamination described in Table 1 


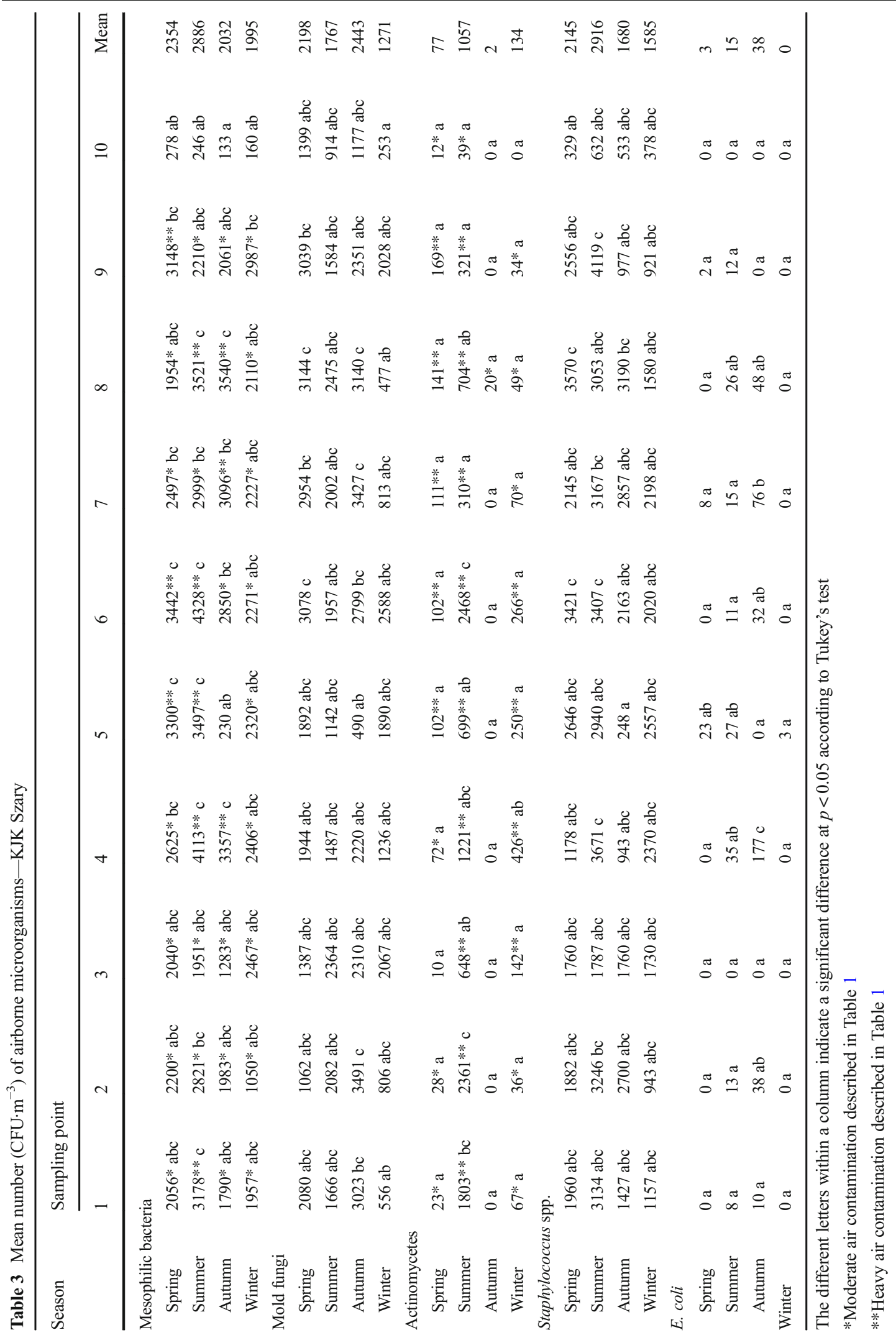


Table 4 Mean number $\left(\mathrm{CFU} \cdot \mathrm{m}^{-3}\right)$ of airborne microorganismsSKH Nielepice

\begin{tabular}{llllll}
\hline Season & \multicolumn{2}{c}{ Sampling point } & & & \\
\cline { 2 - 6 } & 1 & 2 & 3 & 4 & Mean \\
\cline { 2 - 6 } & & & & & \\
Mesophilic bacteria & & & & \\
Spring & $659 \mathrm{a}$ & $470 \mathrm{a}$ & $297 \mathrm{a}$ & $416 \mathrm{a}$ & 460 \\
Summer & $383 \mathrm{a}$ & $374 \mathrm{a}$ & $440 \mathrm{a}$ & $498 \mathrm{a}$ & 424 \\
Autumn & $63 \mathrm{a}$ & $78 \mathrm{a}$ & $65 \mathrm{a}$ & $149 \mathrm{a}$ & 89 \\
Winter & $109 \mathrm{a}$ & $45 \mathrm{a}$ & $118 \mathrm{a}$ & $214 \mathrm{a}$ & 122 \\
Mold fungi & & & & & \\
Spring & $846 \mathrm{a}$ & $1170 \mathrm{a}$ & $1056 \mathrm{a}$ & $898 \mathrm{a}$ & 992 \\
Summer & $1241 \mathrm{a}$ & $1493 \mathrm{a}$ & $1120 \mathrm{a}$ & $706 \mathrm{a}$ & 1140 \\
Autumn & $212 \mathrm{a}$ & $280 \mathrm{a}$ & $310 \mathrm{a}$ & $223 \mathrm{a}$ & 256 \\
Winter & $104 \mathrm{a}$ & $29 \mathrm{a}$ & $36 \mathrm{a}$ & $36 \mathrm{a}$ & 51 \\
Actinomycetes & & & & & \\
Spring & $15 * \mathrm{a}$ & $9 \mathrm{a}$ & $1 \mathrm{a}$ & $33 * \mathrm{a}$ & 15 \\
Summer & $133 * * \mathrm{a}$ & $143 * * \mathrm{a}$ & $65 * \mathrm{a}$ & $140 * * \mathrm{a}$ & 120 \\
Autumn & $0 \mathrm{a}$ & $0 \mathrm{a}$ & $0 \mathrm{a}$ & $30 * \mathrm{a}$ & 8 \\
Winter & $26 * \mathrm{a}$ & $7 \mathrm{a}$ & $10 \mathrm{a}$ & $10 \mathrm{a}$ & 13 \\
Staphylococcus & spp. & & & & \\
Spring & $886 \mathrm{c}$ & $347 \mathrm{ab}$ & $116 \mathrm{a}$ & $198 \mathrm{ab}$ & 387 \\
Summer & $313 \mathrm{ab}$ & $192 \mathrm{ab}$ & $256 \mathrm{ab}$ & $298 \mathrm{ab}$ & 265 \\
Autumn & $270 \mathrm{ab}$ & $65 \mathrm{a}$ & $61 \mathrm{a}$ & $55 \mathrm{a}$ & 113 \\
Winter & $76 \mathrm{a}$ & $15 \mathrm{a}$ & $34 \mathrm{a}$ & $87 \mathrm{a}$ & 53 \\
\hline
\end{tabular}

The different letters within a column indicate a significant difference at $p<0.05$ according to Tukey's test

* Moderate air contamination described in Table 1

**Heavy air contamination described in Table 1

The limit values for the concentration of mesophilic bacteria were not exceeded at KJK Szary in the control point (10) outside the stables and in the point no. 5, in autumn. In all other cases, the air was classified as moderately or heavily polluted with bacteria. The mean concentration of bacteria at KJK Szary was the largest in summer $\left(2886 \mathrm{CFU} \cdot \mathrm{m}^{-3}\right)$ and the smallest in winter $\left(1995 \mathrm{CFU} \cdot \mathrm{m}^{-3}\right)$. The concentration of fungi in the air did not exceed the permissible level of contamination in any of the sampling points. Their average concentration was the highest in autumn $\left(2443 \mathrm{CFU} \cdot \mathrm{m}^{-3}\right)$ and the smallest in winter $\left(1271 \mathrm{CFU} \cdot \mathrm{m}^{-3}\right)$. Large variations in the number of actinomycetes were observed between the sampling points. Therefore, on the basis of their periodic presence in the sampling points, the air was classified as clean or moderately or heavily polluted with these microorganisms. Summer was the season with the highest mean concentration of airborne actinomycetes $\left(1057 \mathrm{CFU} \cdot \mathrm{m}^{-3}\right)$, while autumn was the least favorable for these microorganisms $\left(2 \mathrm{CFU} \cdot \mathrm{m}^{-3}\right)$ and this was the season in which the presence of actinomycetes was not found in any of the sampling points (except point no. 8). During the entire study period, the samples of air collected from the points situated within the stables were heavily polluted with staphylococci. On the other hand, in the control point (no. 10), outside the stable, their concentration was significantly lower. The highest mean concentration of airborne Staphylococcus spp. was observed in summer $\left(2916 \mathrm{CFU} \cdot \mathrm{m}^{-3}\right)$ and the lowest in autumn $\left(1680 \mathrm{CFU} \cdot \mathrm{m}^{-3}\right)$, and winter $\left(1585 \mathrm{CFU} \cdot \mathrm{m}^{-3}\right)$. Small numbers of $E$. coli were detected in most of the sampling points, mostly in summer and autumn (Table 3).

The limit values for the concentrations of airborne bacteria and fungi were not exceeded in SKH Nielepice in any of the sampling points. Therefore, air in SKH Nielepice was classified as uncontaminated with these microorganisms. In contrast, it was found that spring and summer were the seasons in which the mean number of bacteria (460 and $424 \mathrm{CFU} \cdot \mathrm{m}^{-3}$, respectively) and fungi (992 and $1140 \mathrm{CFU} \cdot \mathrm{m}^{-3}$, respectively) was the highest. Similarly as in other horse riding centers, the numbers of actinomycetes varied largely between the sampling points. Therefore, on the basis of their periodic presence in the sampling points, the air was classified as clean or moderately or heavily polluted with these microorganisms. In summer, the mean concentration of airborne actinomycetes was the highest in all sampling points $\left(120 \mathrm{CFU} \cdot \mathrm{m}^{-3}\right)$. During the entire study period, the air samples collected in this horse riding facility was contaminated with staphylococci. However, the numbers of Staphylococcus spp. were by the order of magnitude or even two times smaller than in OJK Pegaz and KJK Szary, which was most probably related to the fact that in SKH Nielepice, all sampling points were situated in the open air. Staphylococci in the air of the SKH Nielepice facility were the most abundant in spring $\left(387 \mathrm{CFU} \cdot \mathrm{m}^{-3}\right)$. E. coli was not detected in any of the sampling points; therefore, these results (0 CFU $\cdot \mathrm{m}^{-3}$ ) were not included (Table 4). 


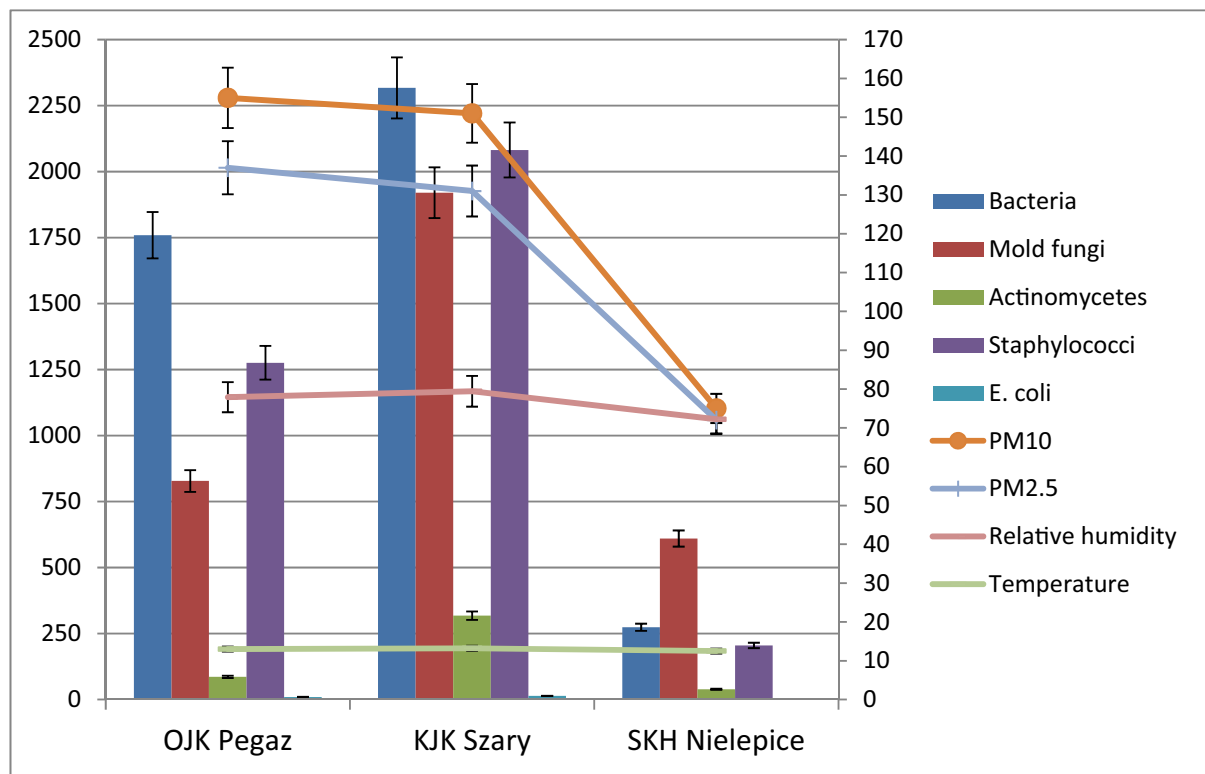

Fig. 1 Mean prevalence of the selected microorganisms $\left(\mathrm{CFU} \cdot \mathrm{m}^{-3}\right)$, particle pollution $\left(\mu \mathrm{g} \cdot \mathrm{m}^{-3}\right)$, relative humidity $(\%)$, and air temperature $\left({ }^{\circ} \mathrm{C}\right)$ in the studied horse riding centers. *The left axis is assigned to bioaerosol; the right axis is assigned to microclimatic parameters

Figure 1 shows mean numbers of the examined microbial groups in the studied horse riding centers over 3 years of the study. Based on the obtained results, it can be concluded that the total number of all examined microorganisms was the highest in KJK Szary, followed by OJK Pegaz and SKH Nielepice.

Regarding the seasonal variation, Budzińska et al. (2016) observed varying concentrations of airborne bacteria in stables - from $1.04 \cdot 10^{5} \mathrm{CFU} \cdot \mathrm{m}^{-3}$ in autumn to $5.90 \cdot 10^{5} \mathrm{CFU} \cdot \mathrm{m}^{-3}$ in summer. On the other hand, the smallest number of bacteria was reported in winter, i.e., $3.74 \cdot 10^{4} \mathrm{CFU} \cdot \mathrm{m}^{-3}$. In the study by Samadi et al. (2009), the numbers of bacteria in the air of stables ranged from $1.22 \cdot 10^{3}$ to $7.82 \cdot 10^{3} \mathrm{CFU} \cdot \mathrm{m}^{-3}$. Dutkiewicz et al. (1994) observed the number of bacteria in the air of stables at the levels varying from $2.6 \cdot 10^{4}$ to $1.5 \cdot 10^{5} \mathrm{CFU} \cdot \mathrm{m}^{-3}$. The concentration of mold fungi in this study did not exceed the limit values included in the Polish Standards (PN-89/Z-04111/03). Budzińska et al. (2016) reported that the concentration of fungi in stables ranged from $1.27 \cdot 10^{3} \mathrm{CFU} \cdot \mathrm{m}^{-3}$ in winter to $4.78 \cdot 10^{4} \mathrm{CFU} \cdot \mathrm{m}^{-3}$ in autumn. On the other hand, the range of concentrations of airborne fungi observed by Witkowska et al. (2012) was $10^{3-} 10^{4} \mathrm{CFU} \cdot \mathrm{m}^{-3}$ and Dutkiewicz et al. (1994) observed the concentrations within the values of $1.7 \cdot 10^{3}-2.8 \cdot 10^{4} \mathrm{CFU} \cdot \mathrm{m}^{-3}$. Prevalence of these microorganisms is strongly associated with the season of the year, air temperature, stocking density, ventilation system, and the hygiene in stables (Dutkiewicz et al. 1994; Budzińska et al. 2016). High concentrations of airborne molds in the stables were also demonstrated by Nardoni et al. (2005), who reported their values reaching from 1750 to $3000 \mathrm{CFU} \cdot \mathrm{m}^{-3}$. Actinomycetes were very abundant in the study by Budzińska et al. (2016), from $3.52 \cdot 10^{3} \mathrm{CFU} \cdot \mathrm{m}^{-3}$ in summer to even $9.03 \cdot 10^{3} \mathrm{CFU} \cdot \mathrm{m}^{-3}$ in spring. Elfman et al. (2009) reported that actinomycetes were very abundant in the air of stables, which was related to the high concentrations of organic dust suspended in the air, affecting their concentrations. At the same time, Elfman et al. (2009) indicated that the highest number of actinomycetes is typical of February and March. In the study by Budzińska et al. (2016), mannitol-positive staphylococci were isolated from the air of stables in the numbers ranging from $0.52 \cdot 10^{1} \mathrm{CFU} \cdot \mathrm{m}^{-3}$ in winter to $3.94 \cdot 10^{1} \mathrm{CFU} \cdot \mathrm{m}^{-3}$ in summer, whereas the numbers of hemolytic staphylococci ranged from $0.43 \cdot 10^{1} \mathrm{CFU} \cdot \mathrm{m}^{-3}$ in spring to $8.62 \cdot 10^{2} \mathrm{CFU} \cdot \mathrm{m}^{-3}$ in summer. Korzekwa et al. (2015) found the lowest mean prevalence of staphylococci in winter - at the level of $157 \mathrm{CFU} \cdot \mathrm{m}^{-3}$ - and the highest in summer-16,008 $\mathrm{CFU} \cdot \mathrm{m}^{-3}$. In summer and autumn, Budzińska et al. (2016) observed the highest numbers of airborne staphylococci, which are the most frequently detected bacteria in livestock premises (Dutkiewicz et al. 1994). Budzińska et al. (2016) detected bacteria from the family of Enterobacteriaceae in the air of stables at the 
levels from $1.38 \cdot 10^{2} \mathrm{CFU} \cdot \mathrm{m}^{-3}$ in winter to $1.02 \cdot 10^{3} \mathrm{CFU} \cdot \mathrm{m}^{-3}$ in summer. The presence of airborne Enterobacteriaceae and particularly E. coli is a cause for concern because it is an epidemiological threat to both humans and animals (Budzińska et al. 2016). According to Zucker et al. (2000), E. coli is an often isolated bacterium from the air of livestock premises. Also, according to Zucker et al. (2000) and Lloyd et al. (2003), airborne E. coli in livestock premises originates from manure.

As shown by other authors (Nardoni et al. 2005; Elfman et al. 2009; Samadi et al. 2009; Witkowska et al. 2012; Korzekwa et al. 2015; Budzińska et al. 2016), the concentration of microorganisms in the stables is subject to changes and is dependent on a number of factors, i.e., microclimatic conditions, temperature, relative humidity, particulate matter concentration, ventilation system, and stocking density. In addition, Witkowska et al. (2012) and Elfman et al. (2009) reported that the number of microorganisms in the air of stables was lower and similar to one another in spring and autumn, while it increased in summer and winter. Witkowska et al. (2012) explained this situation by the fact that in winter, the ventilation in the stables is limited to the minimum, due to the loss of heat; thus, the concentration and survival of microorganisms in the air are higher. On the other hand, in summer, the increase in the number of microorganisms is affected by the higher air temperature.

Tables 5, 6, and 7 show mean values of the following parameters: air temperature, particulate matter concentration $\left(\mathrm{PM}_{10}\right.$ and $\left.\mathrm{PM}_{2.5}\right)$, and relative humidity taking into consideration the seasons of the year and sampling points. The analysis of temperature changes in OJK Pegaz in the analyzed period allowed concluding that there are only small differences in the temperature between the points situated within the stable (no. 1-4) and the control point (no. 5), located outside. Only in the winter, at the control point, the air temperature was below zero and therefore differed significantly from the one observed in the remaining points within the stable. The highest temperature amplitude between the analyzed sampling points, i.e., of $2.4{ }^{\circ} \mathrm{C}$, was found in the winter. Relative humidity was the highest in autumn and winter, and it was observed that in the control point (5), it reached the lowest values in all seasons of the year. The mean values of $\mathrm{PM}_{10}$ concentration during all measurements fall within the range from $49 \mu \mathrm{g} \cdot \mathrm{m}^{-3}$ (summer, control point (5)) to $748 \mu \mathrm{g} \cdot \mathrm{m}^{-3}$ (winter, closed box stall (1)), which corresponds to $98-1496 \%$ of the permissible concentration, i.e., $50 \mu \mathrm{g} \cdot \mathrm{m}^{-3}$ (Regulation 2012). The mean concentrations of $\mathrm{PM}_{2.5}$ during all measurements ranged from $48 \mu \mathrm{g} \cdot \mathrm{m}^{-3}$ (summer, box opening to the outside (3), control point (5), and autumn, box opening to the outside (4)) to $654 \mu \mathrm{g} \cdot \mathrm{m}^{-3}$ (winter, closed box stall (1)), which corresponds to $192-2616 \%$ of the permissible concentration, i.e., $25 \mu \mathrm{g} \cdot \mathrm{m}^{-3}$ (Regulation 2012). The $\mathrm{PM}_{2.5}$ concentration exceeded the permissible values in all sampling points during the entire study period. Analysis of the particulate matter concentration in terms of both $\mathrm{PM}_{10}$ and $\mathrm{PM}_{2.5}$ showed that winter was the season of the year when the transgressions of limits specified in the Regulation (Regulation 2012) were the highest.

Analysis of temperature changes in KJK Szary during the analyzed period allowed concluding that there are also only small differences in the temperature between the points situated within the stable (no. 1-9) and the control point (10), situated outside. The highest temperature amplitude between the analyzed sampling points, i.e., of $3.1^{\circ} \mathrm{C}$, was found between the control point (10), in the open air, and the point no. 5 located within the stable. The temperature in all sampling points was above zero. Relative humidity was the highest in the autumn and winter, and it was observed that in the control point (no. 10), it was the lowest in all seasons of the year. The mean values of $\mathrm{PM}_{10}$ concentration during all measurements ranged from $71 \mu \mathrm{g} \cdot \mathrm{m}^{-3}$ (summer, control point (10)) to $506 \mu \mathrm{g} \cdot \mathrm{m}^{-3}$ (winter, box (5)), which corresponds to $142-1012 \%$ of the permissible concentration of $50 \mu \mathrm{g} \cdot \mathrm{m}^{-3}$ (Regulation 2012). The mean concentrations of $\mathrm{PM}_{2.5}$ during all measurements ranged from $62 \mu \mathrm{g} \cdot \mathrm{m}^{-3}$ (summer, box (7)) to $408 \mu \mathrm{g} \cdot \mathrm{m}^{-3}$ (winter, box (5)), which corresponds to $248-1632 \%$ of the permissible concentration of $25 \mu \mathrm{g} \cdot \mathrm{m}^{-3}$ (Regulation 2012). The concentrations of $\mathrm{PM}_{10}$ and $\mathrm{PM}_{2.5}$ exceeded the permissible levels in all sampling points during the entire study period. Analysis of the particulate matter concentration in terms of both $\mathrm{PM}_{10}$ and $\mathrm{PM}_{2.5}$ showed that winter was the season of the year when the transgressions of limits specified in the Regulation (Regulation 2012) were the highest.

Analysis of temperature changes in SKH Nielepice during the analyzed period allowed concluding again that there are small differences between sampling points situated within the stable. The highest temperature amplitude between the analyzed sampling points — of $1.1^{\circ}$ $\mathrm{C}$ - was found in summer between the points no. 1 (roof for riders) and 2 (saddle room), and 3 (roof for horses). 
Table 5 Mean temperature, relative humidity, and particulate matter concentrations - OJK Pegaz

\begin{tabular}{|c|c|c|c|c|c|c|c|c|}
\hline \multirow[t]{2}{*}{ Sampling point } & \multicolumn{4}{|c|}{ Temperature $\left({ }^{\circ} \mathrm{C}\right)$} & \multicolumn{4}{|c|}{ Relative humidity (\%) } \\
\hline & Spring & Summer & Autumn & Winter & Spring & Summer & Autumn & Winter \\
\hline 1 & 15.3 & 23.9 & 12.4 & 2.8 & 81.2 & 63.9 & 86.1 & 85.4 \\
\hline 2 & 15.4 & 23.6 & 11.6 & 3 & 83.9 & 66 & 91 & 86.8 \\
\hline 3 & 14.4 & 24.3 & 10.1 & 3 & 75.2 & 70.1 & 81.1 & 83.5 \\
\hline 4 & 14.9 & 23.4 & 10.5 & 2.9 & 80.4 & 65.4 & 84.4 & 85.7 \\
\hline 5 & 14.5 & 24.8 & 10.3 & -0.6 & 70.9 & 59.4 & 82.1 & 75.3 \\
\hline Mean & 14.9 & 24 & 11 & 2.2 & 78.3 & 65 & 84.9 & 83.3 \\
\hline \multirow[t]{2}{*}{ Sampling point } & \multicolumn{4}{|c|}{$\mathrm{PM}_{10}\left(\mu \mathrm{g} \mathrm{m}^{-3}\right)$} & \multicolumn{4}{|c|}{$\mathrm{PM}_{2.5}\left(\mu \mathrm{g} \mathrm{m}^{-3}\right)$} \\
\hline & Spring & Summer & Autumn & Winter & Spring & Summer & Autumn & Winter \\
\hline 1 & $98 *$ & $97 *$ & $104 *$ & $748 *$ & $75^{*}$ & $69 *$ & $83 *$ & $654 *$ \\
\hline 2 & $105^{*}$ & $97 *$ & $73 *$ & $714^{*}$ & $92 *$ & $78^{*}$ & $64 *$ & $647 *$ \\
\hline 3 & $55^{*}$ & 50 & $55^{*}$ & $185^{*}$ & $53 *$ & $48^{*}$ & $50 *$ & $166^{*}$ \\
\hline 4 & $64 *$ & $61 *$ & $56^{*}$ & $192 *$ & $56^{*}$ & $50 *$ & $48^{*}$ & $184 *$ \\
\hline 5 & $72 *$ & 49 & $51 *$ & $172 *$ & $61 *$ & $48^{*}$ & $49 *$ & $157 *$ \\
\hline Mean & 79 & 71 & 68 & 402 & 67 & 59 & 59 & 362 \\
\hline
\end{tabular}

* Limit values provided in the Regulation of the Minister of the Environment of 24 August 2012 on the levels of certain substances in the air $\left(\mathrm{PM}_{10}>50 \mu \mathrm{g} \mathrm{m}^{-3}\right.$ and $\left.\mathrm{PM}_{2.5}>25 \mu \mathrm{g} \mathrm{m}^{-3}\right)$

In the winter, the temperature in all sampling points was below zero. Relative humidity was the highest in autumn, with no significant variation in its values between the sampling points in different seasons of the year. The mean values of $\mathrm{PM}_{10}$ concentration during all measurements ranged from $48 \mu \mathrm{g} \cdot \mathrm{m}^{-3}$ (summer, roof for horses (3)) to $103 \mu \mathrm{g} \cdot \mathrm{m}^{-3}$ (autumn, roof for riders (1)), corresponding to $96-206 \%$ of the permissible concentration of $50 \mu \mathrm{g} \cdot \mathrm{m}^{-3}$ (Regulation 2012). The mean concentrations of $\mathrm{PM}_{2.5}$ during all measurements ranged from $47 \mu \mathrm{g} \cdot \mathrm{m}^{-3}$ (summer, roof for horses (3)) to $106 \mu \mathrm{g} \cdot \mathrm{m}^{-3}$ (autumn, roof for riders (1)), corresponding to $188-424 \%$ of the permissible concentration, i.e., $25 \mu \mathrm{g} \cdot \mathrm{m}^{-3}$ (Regulation 2012). The concentration of $\mathrm{PM}_{2.5}$ exceeded the permissible limits in all sampling points, during the entire study period. Analysis of the particulate matter concentration in terms of both $\mathrm{PM}_{10}$ and $\mathrm{PM}_{2.5}$ showed that autumn and winter were the seasons of the year when the transgressions of limits specified in the Regulation (Regulation 2012) were the highest.

The air temperature recorded during the study period did not differ from the values typical for particular seasons of the year in this region of Poland. The temperature measured inside the stables and outside the buildings due to good ventilation of the facilities was often similar. The temperature values in stables measured by Bombik et al. (2011) fell within the range of $8.5-14.4{ }^{\circ} \mathrm{C}$ and outside the buildings $7.4-14.8{ }^{\circ} \mathrm{C}$. On the other hand, Kwiatkowska-Stenzel et al. (2011), while comparing microclimatic conditions in the box-stall stable and in the run pen, found the temperatures within the ranges $-0.9-15.5^{\circ} \mathrm{C}$ and $-7.1-13.4^{\circ}$ C, respectively. Budzińska et al. (2016), depending on the season of the year, recorded the following temperatures in the stables: spring $12.4{ }^{\circ} \mathrm{C}$, summer $21.2{ }^{\circ} \mathrm{C}$, autumn $12.6{ }^{\circ} \mathrm{C}$, and winter $8.2^{\circ} \mathrm{C}$. In this study, temperature was the factor that most significantly affected the prevalence of microorganisms in the air of the tested stables. Higher numbers of microorganisms were recorded in the seasons of the year, when higher temperatures are typical.

In the study by Bombik et al. (2011), relative humidity in the stables was $50.7-83 \%$ and outside the buildings - 51-89.1\%. Budzińska et al. (2016), depending on the season of the year, recorded the following values of relative humidity in the stables: spring $65.4 \%$, summer $60.2 \%$, autumn $74.6 \%$, and winter $76.2 \%$. On the other hand, Kwiatkowska-Stenzel et al. (2011), while comparing microclimatic conditions in the box-stall stable and in the run pen, found the relative humidity of 91.8 and $94 \%$, respectively.

According to the aerodynamic diameter of the particles, particulate matter is classified into two main fractions: $\mathrm{PM}_{10}$ and $\mathrm{PM}_{2.5}$, which air quality monitoring in Poland and Europe refers to (Regulation 2012; 
Table 6 Mean temperature, relative humidity, and particulate matter concentrations - KJK Szary

\begin{tabular}{|c|c|c|c|c|c|c|c|c|}
\hline \multirow[t]{2}{*}{ Sampling point } & \multicolumn{4}{|c|}{ Temperature $\left({ }^{\circ} \mathrm{C}\right)$} & \multicolumn{4}{|c|}{ Relative humidity (\%) } \\
\hline & Spring & Summer & Autumn & Winter & Spring & Summer & Autumn & Winter \\
\hline 1 & 12.5 & 23.7 & 13 & 2.4 & 78.9 & 67.3 & 85.4 & 91.6 \\
\hline 2 & 13.1 & 22.4 & 13.4 & 3.1 & 85.9 & 68.1 & 87.1 & 90.2 \\
\hline 3 & 13.3 & 22.3 & 13.7 & 3.7 & 76.6 & 71.2 & 85.3 & 87.7 \\
\hline 4 & 13.5 & 22.6 & 13.8 & 3.2 & 82.5 & 66.4 & 83.7 & 87.7 \\
\hline 5 & 14.4 & 22.2 & 13.6 & 4.1 & 82.6 & 67.6 & 88.6 & 87.4 \\
\hline 6 & 14.3 & 22.6 & 13.9 & 3.7 & 84.8 & 67 & 87 & 87.7 \\
\hline 7 & 12.8 & 22.3 & 13.4 & 3.2 & 74.6 & 74.1 & 82 & 87 \\
\hline 8 & 13.1 & 21.7 & 13.5 & 3.6 & 75.9 & 62.4 & 79.8 & 90.9 \\
\hline 9 & 13.5 & 22.3 & 13.8 & 3.7 & 80.7 & 67.1 & 85.5 & 85.9 \\
\hline 10 & 13.2 & 23.5 & 14.5 & 1 & 72.4 & 63.5 & 74.9 & 72 \\
\hline Mean & 13.4 & 22.6 & 13.7 & 3.2 & 79.5 & 67.5 & 83.9 & 86.8 \\
\hline \multirow[t]{2}{*}{ Sampling point } & \multicolumn{4}{|c|}{$\mathrm{PM}_{10}\left(\mu \mathrm{g} \mathrm{m}^{-3}\right)$} & \multicolumn{4}{|c|}{$\mathrm{PM}_{2.5}\left(\mu \mathrm{g} \mathrm{m}^{-3}\right)$} \\
\hline & Spring & Summer & Autumn & Winter & Spring & Summer & Autumn & Winter \\
\hline 1 & $88^{*}$ & $135^{*}$ & $82 *$ & $372 *$ & $68 *$ & $84 *$ & $75^{*}$ & $364^{*}$ \\
\hline 2 & $93^{*}$ & $78^{*}$ & $93 *$ & $391 *$ & $77 *$ & $69 *$ & $78^{*}$ & $382^{*}$ \\
\hline 3 & $97^{*}$ & $100^{*}$ & $110^{*}$ & $406^{*}$ & $82 *$ & $80 *$ & $92 *$ & $395^{*}$ \\
\hline 4 & $91^{*}$ & $100^{*}$ & $74 *$ & $336^{*}$ & $63 *$ & $76^{*}$ & $69 *$ & $305^{*}$ \\
\hline 5 & $76^{*}$ & $90 *$ & $76^{*}$ & $506^{*}$ & $63 *$ & $68 *$ & $68^{*}$ & $408^{*}$ \\
\hline 6 & $119^{*}$ & $98^{*}$ & $97^{*}$ & $296^{*}$ & $78 *$ & $77 *$ & $90 *$ & $261 *$ \\
\hline 7 & $101^{*}$ & $69 *$ & $104 *$ & $299 *$ & $80 *$ & $62 *$ & $95^{*}$ & $272^{*}$ \\
\hline 8 & $148^{*}$ & $94 *$ & $102 *$ & $282 *$ & $88 *$ & $75^{*}$ & $88^{*}$ & $245^{*}$ \\
\hline 9 & $87^{*}$ & $73 *$ & $91^{*}$ & $225^{*}$ & $73 *$ & $66^{*}$ & $87 *$ & $203^{*}$ \\
\hline 10 & $72 *$ & $71 *$ & $74 *$ & $136^{*}$ & $63 *$ & $64 *$ & $68^{*}$ & $118 *$ \\
\hline Mean & 97 & 91 & 90 & 325 & 74 & 72 & 81 & 295 \\
\hline
\end{tabular}

*Limit values provided in the Regulation of the Minister of the Environment of 24 August 2012 on the levels of certain substances in the air $\left(\mathrm{PM}_{10}>50 \mu \mathrm{g} \mathrm{m}^{-3}\right.$ and $\left.\mathrm{PM}_{2.5}>25 \mu \mathrm{g} \mathrm{m}^{-3}\right)$

Table 7 Mean temperature, relative humidity, and particulate matter concentrations-SKH Nielepice

\begin{tabular}{|c|c|c|c|c|c|c|c|c|}
\hline \multirow[t]{2}{*}{ Sampling point } & \multicolumn{4}{|c|}{ Temperature $\left({ }^{\circ} \mathrm{C}\right)$} & \multicolumn{4}{|c|}{ Relative humidity (\%) } \\
\hline & Spring & Summer & Autumn & Winter & Spring & Summer & Autumn & Winter \\
\hline 1 & 13 & 22.8 & 13.6 & -0.1 & 71.1 & 58.8 & 80.3 & 74.4 \\
\hline 2 & 12.9 & 23.9 & 13.4 & -0.1 & 73.5 & 65.2 & 78.8 & 69.4 \\
\hline 3 & 12.9 & 23.9 & 13.5 & -0.3 & 73.4 & 65.9 & 77 & 76.7 \\
\hline 4 & 13 & 23.5 & 13.3 & -0.3 & 72 & 68.3 & 80.2 & 69.4 \\
\hline Mean & 13 & 23.5 & 13.5 & -0.2 & 72.5 & 64.6 & 79.1 & 72.5 \\
\hline \multirow[t]{2}{*}{ Sampling point } & \multicolumn{4}{|c|}{$\mathrm{PM}_{10}\left(\mu \mathrm{g} \mathrm{m}^{-3}\right)$} & \multicolumn{4}{|c|}{$\mathrm{PM}_{2.5}\left(\mu \mathrm{g} \mathrm{m}^{-3}\right)$} \\
\hline & Spring & Summer & Autumn & Winter & Spring & Summer & Autumn & Winter \\
\hline 1 & $87 *$ & $53 *$ & $103 *$ & $78^{*}$ & $82 *$ & $52 *$ & $106^{*}$ & $73 *$ \\
\hline 2 & $76^{*}$ & 50 & $87 *$ & $84 *$ & $72 *$ & $48^{*}$ & $83 *$ & $79 *$ \\
\hline 3 & $73 *$ & 48 & $74 *$ & $89 *$ & $70 *$ & $47 *$ & $72 *$ & $83 *$ \\
\hline 4 & $77 *$ & 50 & $86^{*}$ & $90 *$ & $74 *$ & $48 *$ & $82 *$ & $76^{*}$ \\
\hline Mean & 78 & 50 & 88 & 85 & 75 & 49 & 86 & 78 \\
\hline
\end{tabular}

*Limit values provided in the Regulation of the Minister of the Environment of 24 August 2012 on the levels of certain substances in the air $\left(\mathrm{PM}_{10}>50 \mu \mathrm{g} \mathrm{m}^{-3}\right.$ and $\left.\mathrm{PM}_{2.5}>25 \mu \mathrm{g} \mathrm{m}^{-3}\right)$ 
Marcazzan et al. 2001). The transgressions of $\mathrm{PM}_{10}$ and $\mathrm{PM}_{2.5}$ limit values, recorded in this study, are due to both smog occurring in Kraków and the specific character of the examined livestock premises (Pawul and Śliwka 2016).

Based on the statistical analysis of the obtained results, it was found that in all three horse riding centers, the correlation between the abundance of selected groups of microorganisms and microclimate conditions (temperature and humidity of air, $\mathrm{PM}_{10}$, and $\mathrm{PM}_{2.5}$ ) was positive in the case of temperature and negative for the other analyzed factors. This is probably due to the fact that in the winter months due to low temperatures, the number of microorganisms was lower, even though the general particulate matter concentration was greater. This is most probably caused by the occurrence of smog phenomenon in this region of Poland, which becomes particularly troublesome during the heating season. However, the analysis showed a significant correlation between the concentration of bioaerosol and temperature (for bacteria: $r=0.99 ; p<0.05$ ), of bioaerosol and particulate matter-both fractions $\mathrm{PM}_{10}$ and $\mathrm{PM}_{2.5}$ (for mold fungi: $r=-0.95$, Staphylococcus spp.: $r=-$ $0.96 ; p<0.05$ ) in OJK Pegaz, a significant correlation between the concentration of bioaerosol and air humidity (both for bacteria and Staphylococcus spp.: $r=-0.99 ; p<0.05)$ in KJK Szary, a significant correlation between the concentration of bioaerosol and particulate matter-fractions $\mathrm{PM}_{10}$ and $\mathrm{PM}_{2.5}$ (for actinomycetes accordingly: $r=-$ $0.98, r=-0.97 ; p<0.05)$ in SKH Nielepice.

As shown in Fig. 1, air pollution with both fractions of particles was clearly higher in OJK Pegaz and KJK Szary than in SKH Nielepice. In the case of temperature and relative humidity values, differences between horse riding centers are not so evident. It is suggested that this situation results from the differences in the horse keeping systems. In the centers that run the box-stall system of horse keeping, the animals spend a lot of time in their boxes. Many care and cleaning operations are carried out on a limited, closed space. In addition, there is manure in the boxes and there are feed, straw, and hay for horses in the farmhouses, constituting the source of particulate pollution of air (Fleming et al. 2008). Although the KJK Szary is a modern and well-ventilated facility, the $\mathrm{PM}_{10}$ and $\mathrm{PM}_{2.5}$ concentration was comparably high to the one recorded in smaller and older facility, which is OJK Pegaz. Nevertheless, it should be added that the high concentrations of particulate matter, also in SKH Nielepice, were also the result of generally poor air quality in Lesser Poland, where the problem of air pollution has been observed for many years (Pawul and Śliwka 2016). This is particularly evident during the heating season, which is winter in the Polish climate. Unfortunately, many fireplaces burn low-quality fuel, and sometimes even garbage and waste. Therefore, the problem of particle pollution in the horse riding centers should be perceived in two ways, i.e., as the effect of generally bad air quality but also as the specific characteristic of the livestock premises. It is justified in the stables to undertake activities aimed at reducing the $\mathrm{PM}_{2.5}$ and $\mathrm{PM}_{10}$ dust content and the bioaerosol concentration. It is necessary to remove manure every day and replace bedding with a new one. In addition, straw, hay, and fodder should be stored in separate, specially designed premises. Daily airing of the stable in the absence of mechanical ventilation is also a good concept. All care treatments, i.e., horse haircut and brushing, should be performed in specially designated area or outside the stables. This approach can contribute to improving the air quality in the stable and have a positive impact on the health of horses and people working with them.

\section{Conclusions}

On the basis of the results obtained, it can be concluded that the air pollution is higher in the horse riding centers with the box-stall horse keeping system. Particularly high transgressions of the limit values were observed in the largest analyzed facility-KJK Szary. In addition, the concentration of bioaerosol also depended on the temperature and humidity of air and was subject to seasonal fluctuations. High concentration of particulate matter $\mathrm{PM}_{10}$ and $\mathrm{PM}_{2.5}$ occurring mostly in the facilities with the box-stall horse keeping system-KJK Szary and OJK Pegaz-is also the reason for the increase of microbial air pollution. The presence of airborne E. coli, Staphylococcus spp., 
actinomycetes, and mold fungi, observed in this study, and therefore also their metabolites and toxins, can cause illness in both horses and people staying around them. Therefore, regardless of the horse keeping system, the conditions in which the animals stay must be optimal and tailored to their needs in order to maintain them in good health and condition and to prevent the exposure of people who stay around them to the harmful effects of bioaerosol.

Acknowledgments The author would like to sincerely thank Mr. Marian Mikołajewicz (The Hutsul Pony Stud Farm in Nielepice), Mr. Bogdan German (The Horse Riding Center Pegaz in Kraków), and Mrs. Anna Szary-Ziębicka (The Horse Riding Club Szary in Michałowice) for allowing this research and valuable help during the study.

Funding information This study was funded by the statutory measures of the Department of Microbiology, University of Agriculture in Cracow, Poland.

Open Access This article is distributed under the terms of the Creative Commons Attribution 4.0 International License (http:// creativecommons.org/licenses/by/4.0/), which permits unrestricted use, distribution, and reproduction in any medium, provided you give appropriate credit to the original author(s) and the source, provide a link to the Creative Commons license, and indicate if changes were made.

\section{References}

Bombik, E., Bombik, T., \& Frankowska, A. (2011). Evaluation of selected parameters of horse stabling environment in boxstall stables. Acta Scientiarum Polonorum Zootechnica, 10 (4), 13-22.

Budzińska, K., Szejniuk, B., Jurek, A., Michalska, M., Traczykowski, A., \& Berleć, K. (2016). Evaluation of selected physical and microbiological parameters of air in a boxstall stable. Acta Scientiarum Polonorum Zootechnica, 15(1), 3-18.

Chang, C. W., Chung, H., Huang, C. F., \& Su, H. J. J. (2001). Exposure of workers to air borne microorganisms in open-air swine houses. Applied and Environmental Microbiology, 67 (1), 155-161.

Chmiel, M. J., Frączek, K., \& Grzyb, J. (2015). The problems of microbiological air contamination monitoring. WaterEnvironment-Rural Areas, 15(1), 17-27 (In Polish).

Domsch, K. H., Gams, W., Anderson, T. H. (1980). Compendium of soil fungi. Londyn.

Duchaine, C., Grimard, Y., \& Cormier, Y. (2000). Influence of building maintenance, environmental factors, and seasons on airborne contaminants of swine confinement buildings. American Industrial Hygiene Association, 61(1), 56-63.

Dutkiewicz, J., Pomorski, Z. J. H., Sitkowska, J., KrysińskaTraczyk, E., Skórska, C., Prażmo, Z., Cholewa, G., \&
Wójtowicz, H. (1994). Airborne microorganisms and endotoxin in animal houses. Grana, 33(2), 85-90.

Elfman, L., Riihimäki, M., Pringle, J., \& Walinder, R. (2009). Influence of horse stable environment on human airways. Journal of Occupational Medicine and Toxicology, 4, 10.

Fleming, K., Hessel, E. F., \& Van den Weghe, H. F. A. (2008). Evaluation of factors influencing the generation of ammonia in different bedding materials used for horse keeping. Journal of Equine Veterinary Science, 28(4), 223-231.

Frąk, M., Majewski, G., \& Zawistowska, K. (2014). Analysis of the quantity of microorganisms adsorbed on particulate matter $\mathrm{PM}_{10}$. Scientific Review - Engineering and Environmental Sciences, 64, 140-149 (In Polish).

Gołofit-Szymczak, M., \& Górny, R. L. (2010). Bacterial and fungal aerosols in air-conditioned office buildings in Warsaw, Poland - the winter season. International Journal of Occupational Safety and Ergonomics, 16(4), 465-476.

Górny, R. L., \& Dutkiewicz, J. (2002). Bacterial and fungal aerosols in indoor environment in Central and Eastern European countries. Annals of Agricultural and Environmental Medicine, 9, 17-23.

Holt, J. G. (red.) (1994). Bergey's manual of determinative bacteriology. 9-th ed. Baltimore. Williams \& Wilkins. ISBN 0683-00603-7.

Korzekwa, K., Łuczyńska, M., \& Sosińska, M. (2015). Importance of microbiological research of bioaerosols during horse breeding. Journal of Central European Agriculture, 16 (4), 357-369.

Kwiatkowska-Stenzel, A., Sowińska, J., Mituniewicz, T., Iwańczuk-Czernik, K., Wójcik, A., \& Radzymińska, M. (2011). The comparison of horses management conditions in the box stall stable and the horse-barn. Polish Journal of Natural Sciences, 26(1), 27-36.

Lloyd, D. H., Littlewood, J. D., Craig, J. M., \& Thomsett, L. R. (2003). Practical equine dermatology. Oxford: Blackwell Science.

Marcazzan, G. M., Vaccaro, S., Valli, G., \& Vecchi, R. (2001). Characterisation of $\mathrm{PM}_{10}$ and $\mathrm{PM}_{2.5}$ particulate matter in the ambient air of Milan (Italy). Atmospheric Environment, 35 (27), 4639-4650.

Nardoni, S., Mancianti, F., Sgorbini, M., Taccini, F., \& Corazza, M. (2005). Identification and seasonal distribution of airborne fungi in three horse stables in Italy. Mycopathologia, 160(1), 29-34.

Operator's Manual MAS-100TM professional Microbial Air Monitoring System for the Microbiological Testing of Air. Brussels, Belgium.

Pawul, M., \& Śliwka, M. (2016). Application of artificial neural networks for prediction of air pollution levels in environmental monitoring. Journal of Ecological Engineering, 17(4), 190-196.

PN-89/Z-04111/02. (1989). Air purity protection. Microbiological testings. Determination of the number of bacteria in the atmospheric air (imission) with sampling by aspiration and sedimentation. Warsaw, Poland: Polish Committee for Standardization (In Polish).

PN-89/Z-04111/03. (1989). Air purity protection. Microbiological testings. Determination of the number of fungi in the atmospheric air (imission) with sampling by aspiration and sedimentation. Warsaw, Poland: Polish Committee for Standardization (In Polish). 
PN-Z-04008-08. (1989). Air purity protection - sampling - sampling of atmospheric air (imission) for microbiological research by aspiration and sedimentation. Warsaw, Poland: Polish Committee for Standardization (In Polish).

Regulation of the Minister of Environment on the concentrations of selected substances in ambient air (2012). 24 August 2012, published in Dz.U. Item 1031 (In Polish).

Samadi, S., Wouters, I. M., Houben, R., Jamshidifard, A. R., Van Eerdenburg, F., \& Heederik, D. J. (2009). Exposure to inhalable dust, endotoxins, beta(1->3)-glucans, and airborne microorganisms in horse stables. Annals of Occupational Hygiene, 53, 595-603.

Waran, N. (2002). Welfare of horses (pp. 79-80). Secaucus, NJ, USA: Kluwer Academic Publishers.
Witkowska, D., Kwiatkowska-Stenzel, A., Jóźwiak, A., Chorąży, Ł., \& Wójcik, A. (2012). Microbiological contamination of air inside and around stables during different seasons of the year. Polish Journal of Environmental Studies, 21(4), 10611066.

Wolny-Koładka, K., \& Malina, D. (2017). Silver nanoparticles toxicity against airborne strains of Staphylococcus spp. Journal of Environmental Science and Health, Part A, 52, 1247-1256. https://doi.org/10.1080/10934529.2017.1356186.

Zucker, B. A., Trojan, S., \& Müller, W. (2000). Airborne gramnegative bacterial flora in animal houses. Journal of Veterinary Medicine, Series B, 47(1), 37-46. 